\title{
EPISTIMOLOGI ILMU EKONOMI ISLAM ANALISIS PERSPEKTIF FILSAFAT ILMU
}

\author{
Iskandar Budiman \\ Fakultas Ekonomi dan Bisnis Islam IAIN Langsa \\ Iskandarbudiman@iainlangsa.ac.id
}

\begin{abstract}
This paper focuses on the epistemology of Islamic economics which is examined by using the philosophy of science as a tool of analysis. From the study, it was found that economics should be analyzed using the philosophy of science. Philosophy of science as a process of elaborating on the characteristics of scientific disciplines (scientific discipline) and how to obtain them (epistemic), is very likely to be used as a basic reference for the development of Islamic economics.
\end{abstract}

Keywords: Islamic philosophy, epistemology of Islamic economics

\begin{abstract}
Abstrak
Tulisan ini focus pada epistimilogi ilmu ekonomi Islam yang ditelaah dengan menjadikan filsafat ilmu sebagai pisau analisis. Dari kajian didapatkan ilmu ekonomi sepatutnya ditelaah dengan menggunakan filsafat ilmu. Filsafat ilmu sebagai sebuah proses pengelaborasian tentang karakteristik disiplin ilmiah (scientific discipline ) dan bagaimana cara memperolehnya (epistimic), menjadi hal yang sangat mungkin sekali untuk dijadikan referensi dasar sebagai pengembangan ekonomi Islam
\end{abstract}

Kata Kunci :Filsafat Islam, Epistimologi, dan Ekonomi Islam.

\section{Pendahuluan}

Islam bukan sekedar menawarkan pedoman-pedoman moral teoritis guna membangun sistem ekonomi, tapi juga mengemukakan suatu metodologi yang layak untuk menerapkan pedoman-pedoman dengan ke absahan cara dan juga legitimasi tujuan dengan landasan atas 
pertimbangan etika yang jelas dan dapat bemakna di dalam keseluruan kerangka tata sosial, dengan pendekatan terhadap sistem ekonomi ini sangat relevan dan amat mendesak untuk di alamatkan pada syari'ah dengan sistem ekonomi Islam (Huda 2007:1).

Pada masa dahulu aplikasinya sangat sederhana dan berlangsung antara dua pihak. Pada masa sekarang ketika mudharabah masuk dalam dunia perbankan aplikasinya mengalami pengembangan. Demikian pula penerapan bai'istishna' dalam pembangunan suatu proyek. Ini adalah pengembangan dari konsep jual biasa yang diajarkan al-Quran dan Sunnah. Tugas cendikiawan muslim sepanjang sejarah adalah mengembangkan teknik penerapan prinsip-prinsip tersebut sesuai dengan situasi, kondisi dan perkembangan zaman. Dengan demikian ciri khas aspek muamalat (ekonomi) adalah cakupannya yang luas dan bersifat elastis, berkembang sesuai dengan perkembanganzaman dan perubahan tempat. Ajaran muamalat khususnya dalam ekonomi lebih tampak sifat universalnya, (Qardhawi 1987:67).

Hal ini karena dalam bermuamalat di bidang ekonomi tidak membedabedakan muslim dan non-muslim. Kenyataan ini tersirat dalam suatu ungkapan yang diucapkan oleh Khalifah Ali bahwa dalam bidang muamalat kewajiban mereka adalah kewajiban kita dan hak mereka adalah hak kita. Filsafat ekonomi, merupakan dasar dari sebuah sistem ekonomi yang dibangun. Berdasarkan filsafat ekonomi yang ada dapat diturunkan tujuan-tujuan yang hendak dicapai, misalnya tujuan kegiatan ekonomi konsumsi, produksi, distribusi, pembangunan ekonomi, kebijakan moneter, kebijakan fiskal, dan sebagainya (Nasution 1991:245).

\section{Pengertian Filsafat}

Secara etimologi sfilsafat berasal dari bahasa Yunani; philosophia, yang terdiri dari dua kata yaitu philo dan sophia. Philo berarti cinta dalam arti luas, yakni keinginan dan Sophia berate hikmat (kebijaksanaan) atau kebenaran. Jadi secara etimologi, filasafat berarti cinta kebijaksanaan atau kebenaran (Tafsir 1990:8). Pengertian filsafat secara terminology sangat beragam, baik dalam ungkapan maupun titik tekannya. Mohammad Hatta dan Langeveld mengatakan bahwa filsafat tidak perlu didefinisikan karena setiap orang memiliki titik tekan sendiri dalam definisinya. Oleh karena itu biarkan saja orang meneliti filsafat terlebih dahulu kemudian menyimpulkannya sendiri, (Tafsir 1990:8).

Berdasarkan telaahsejak zaman Yunani kuno sampai dengan sekarang, beberapa ahli filsafat telah mendifinisikan bidang kajian ini. Misalnya, Plato menyatakan filsafat sebagai ilmu pengetahuan yang berminat mencapai kebenaran yang murni. Murid Plato, Aristoteles mendefinisakan filsafat sebagai ilmu pengetahuan yang meliputi kebenaran, seperti ilmu-ilmu metafisika, logika, retorika, etika, ekonomi, politik, danestetika. Descartes mendifinisikan filsafat sebagaikumpulan segala ilmu pengetahuan termasuk di dalamnya Tuhan, alam dan manusia menjadi pokok penyelidikan, (Wiramihardja 2006:11). 
Al-Farabi mengatakan bahwa filsafat adalah pengetahuan tentang alam yang maujud dan bertujuan menyelidiki hakikat yang sebenarnya (Tafsir 1990:9). Pengertian filsafat menurut Fuad Hassan adalah, suatu ikhtiar untuk berfikir radikal; radikal dalam arti radix-nya suatu gejala; dari akarnya sesuatu yang hendak dipermasalahkan. Dan dengan jalan penjagaan yang radikal itu filsafat berusaha untuk sampai kepada kesimpulan yang universal (Hassan 1989:10). Harun Nasution mengatakan bahwa, filsafat adalah berpikir menurut tatatertib (logika) dengan bebas (tidak terikat pada tradisi, dogma, dan agama) dan dengan sedalam-dalamnya, sehingga sampai kedasar-dasar persoalan (Iswadi 2007:48-57).

\section{Pengembangan Ilmu Ekonomi Islam dari Perspektif Filsafat Ilmu}

Lahir sistem ekonomi Islam pada pertengahan dasawarsa 70-an, merupakan sebuah respon dari dampak negatif ilmu ekonomi yang dikembangakan oleh ilmuan Barat. Jargon yang diusung adalah maksima- lisasi tanpa harus melirik siapa saja yang terlindas oleh roda individulistik, materia- listik, dan hedonistic (Iswadi 2007:48-57). Ketidakadilan, ketimpangan, kemiskinan, dan kelaparan merupakan sebagian fenomena yang sudah tidak aneh lagi untuk disaksikan.

Perkembangan ekonomi Islam, jika ditelusuri sejak zaman Nabi atau setidaknnya dari tahun 70-an hingga zaman kontemporer sekarang menunjukkan terjadinya perkembangan yang signifikan dalam body of Islamic economics. Namun dipihak lain, dominanisasi praktek ilmu ekonomi Islam semakin menajam di sektor perbankan dan misi keagamaan, yang bersifat memihak, subjektif, sehingga mendorong adanya unsur pemaksaan untuk menerapkan begitu saja model-model transaksi fikihyang lebih sering bersifat ideologis ketimbang obyektif ilmiah ke dalam praktek ekonomi modern. Hal itu hanya akan mewujudkan sistem ekonomi Islam yang amaliah saja, tanpa ada unsur ilmiahnya. Keadaan semacam inilah yang perlu diatasi dengan strategi pengembangan ilmu dan kajian yang lebih mendalam.

Sejarah pemikiran dan perkembang- an ekonomi Islam telah membuka cakrawala pengetahuan kita bahwa ilmu ekonomi Islam bukanlah barang jadi yang hanya selesai dalam satu kali proses atau pun langsung turun dari langit secara mendadak. Ekonomi Islam lahir melalui proses bertahap dan evolutif sehingga bukanlah sebuah kesalahan jika ditinjau kembali secara kritis berdasarkan realitas yang ada dan berkembang. Beragam realitas sudah barang tentu sedikit banyak terlibat dalam melukiskan panorama bangunan ekonomi Islam hingga turut serta dalam mengendalikan haluannya. Kondisi masyarakat dari masa ke masa yang berubah-ubah merupakan hal utama dalam menciptakan fleksibelitas kebijakan ekonom muslim dalam menciptakan kesejahteraan bersama.

Keterikatan nilai-nilai yang diajarkan agama dengan pengembangan ilmu ekonomi merupakan sebuah keharusan. Namun masalahnya adalah bagaimana menempatkan agama agar bisa dihayati secara utuh dengan menjadikan nilainilai yang terkandung didalamnya sebagai ruh pengembangan ilmu ekonomi, agar tidak menimbulkan kemudaratan bagi umat manusia. Ketika metodologi 
ilmiah sudah tidak lagi terlalu diperhatikan dalam rangka konseptualisai ilmu ekonomi Islam karena dominannya wilayah keagamaan, maka ketika itu pula akan terjadi persoalan yang harus dibicarakan lebih mendalam. Apalagi, sebenarnya selama ini wilayah keagamaan yang dianggap oleh sebagian pihak adalah hanyalah hasil rasionalisasi ulama klasik terdahulu, seperti fikih, ilmu tafsir dan sebagainya.

Berdasarkan fakta di atas, maka diperlukan adanya keselarasan antara wilayah keagamaan dengan wilayah keilmuan sehingga agama tidak lagi menjadi kambing hitam atas tafsiran ulama yang sudah tidak lagi relevan dengan zamannya lantaran bertentangan dengan keilmuan modern yang sudah barang tentu berbeda dengan keilmuan klasik. Dengan kata lain, pendekatan yang ditawarkan adalah pendekatan yang melibatkan dua model sekaligus: normatifidealis-deduktif dan historis-emipiris-induktif (Minhaji 2008:14).

Berkaitan dengan hal di atas, kisah bantahan dogma gereja atas ilmu pengetahuan pada abad pertengahan karena tafsir yang salah dapat dijadikan sebagai sebuah pelajaran. Fakta sejarah ini telah memancing reaksi tersendiri bagi ilmuan Barat, sehingga menampakkan kecenderungan untuk menangkis adanya intervensi agama dalam mengembangkan ilmu pengetahuan. Agama sebagai sumber nilai kemudian dipandang sebagai sebuah ilusi yang tidak mampu menjawab berbagai rintangan dan tantangan kehidupan modern yang serba kompleks. Sigmund Freud, bahkan lebih lantang mengemukakan bahwa agama merupakan ilusi yang didasarkan pada kehendak manusia (human wishes) daripada realitas. Karena itu, agama mempunyai masa depan yang suram karena tidak cocok dengan kecenderungan ilmiah rasional dan akhirnya tidak akan bertahan di dunia modern.

Kekhawatiran yang melanda sebagian ilmuan Barat, seharusnya menjadi pelajaran bagi agamawan, ekonom muslim, dan siapa saja yang punya minat dan motivasi untuk mengembangkan ilmu ekonomi Islam karena tidak menutup kemungkinan pengembangan ilmu ekonomi Islam pun akan terhambat lantaran terlalu terbebani dengan wilayah normatif-subjektif dan cenderung ringan dengan aspek yang objektif ilmiah. Sesungguhnya dalam Islam, kehidupan ekonomi dan agama merupakan satu kesatuan yang tidak terpisahkan, tapi dapat dibedakan. Keduanya berhubungan secara dialektis tanpa berhenti pada satu sisi. Keduanya menyatu menjadi satu kesatuan yang flowing dan fluid tetapi tidak macet dalam satu sisi. Jika tidak demikian, akan terjadi proses dominasi yang satu atas lainnya, sehingga menepikan aspek keilmiahan atau sebaliknya akan menepikan aspek normativitas yang sarat akan nilai-nilai untuk kesejahteraan. Secara metodologis, pengembangan ekonomi Islam secara normatif-idealis-deduktif bukanlah sesuatu yang salah, namun hanya akan menjadikan ekonomi Islam sebatas ekonomi etik atau ekonomi yang bermoral, yang kerapakali hanya bisa menjadi pengkritik saja. Dalam rangka merumuskan sebuah sistem yang bisa dijadikan sebagai postulat pengembangan ekonomi Islam, diperlukan adanya metode historis-empiris-induktif berdasarkan realitas dan emperikal aktivitas perekonomian masyarakat yang sedang berkembang. 
Ilmu ekonomi Islam tidak akan berkembang secara berarti dalam mengejar ketertinggalannya juga tidak akan banyak membantu dalam membuahkan hasil yang optimal jika misi keagamaan masih dominan dan kajian yang bersifat objektif ilmiah masih cenderung lamban. Harus diakui bahwa ilmu ekonomi Islam yang pernah ada dari awal perkembangan sejarah Islam hingga sekarang bukanlah sebuah sistem yang sempurna bisa diaplikaskan kapan saja. Dengan demikian, perlu dikonseptualisasi seiring dengan perkembangan zaman yang semakin kompleks. Oleh karena itu, agamawan dan ekonom muslim jangan terjebak dengan pola pikir menara gading yang hanya berpikir murni dalam bidangnya tanpa mengaitkan dengan kenyataan yang ada diluarnya karena setiap aktivitas keilmuan ekonomi Islam tidak dapat dilepaskan dari konteks kehidupan sosial kemasyarakatan yang mengitarinya.

Perjalanan dan perkembangan ilmu ekonomi Islam ditinjau secara filosofisepistimologis bergerak lebih tajam ke wilayah bayani dan irfani dengan sedikit menomorduakan penggunaan rasio (burhani) secara maksimal. Hal ini tentu tidak senada dengan praktek yang pernah dilakukan pada masa keemasan keilmuan Islam antara tahun $650 \mathrm{M}$ samapai $1100 \mathrm{M}$. Inilah faktor yang diduga oleh berbagai kalangan, memberi imbas ketertinggalan umat Islam dalam bidang ilmu pengetahuan, tak terkecuali dengan ilmu ekonomi Islam. Sebagai perbandingan, kajian epistimologis dalam literatur Barat dapat membuka perspektif baru dalam kajian ilmu ekonomi yang multidimensional. Studi yang dilakukan oleh sejumlah ilmuan menunjukkan bahwa paradigma keilmuan modern (Barat), termasuk pembangunan ekonomi didasarkan pada filsafat positivisme yang rasionalistikempiris. Ia tidak menerima sesuatu yang bersifat subjektif, kebenaran yang diterima adalah kebenaran positivistik yang dapat diukur dan dijangkau oleh radius inderawi manusia. Kebenaran model ini berlandaskan pada paradigma raionalitas Cartesian dengan semboyannnya yang terkenal cogito ergo sum atau I think, therefore I am (Saya berfikir, karena itu saya ada) (Suyatno 1997:22).

Namun dalam perkembangannya, ilmu ekonomi Barat dihadapkan secara dikotomis dengan nilai trasendental sehingga jargon ilmu ekonomi bebas nilai (value free), tidak saja mempengaruhi di kalangan akademisi, tetapi juga mewarnai praktek-praktek ekonomi masyarakat modern. Nilai trasendental dan nilai humanis yang seharusnya berjalan seirama mengalami fragmentasi dan pada akhirnya nilai trasendental betul-betul mengalami distorsi, alienasi, dan marginalisasi. Akibatnya kemudian yang ada hanyalah keserakahan yang tidak berujung di satu sisi dan kemelaratan abadi disisi yang lain.

Belajar dari kesalahan ilmuan Barat yang telah lepas dari nilai yang mengikatnya, maka ekonomi Islam sebagai sebuah bangunan ilmu yang memiliki tujuan duniawi dan ukhrowi, seharusnya lebih meyakinkan unifikasi tersebut dalam perkembangannya. Sebagai ilmu ekonomi yang berbasis nilai dan tidak mengenal dikotomi, maka kehadiran ekonomi Islam diyakini sebagai penawar di tengah persoalan fundamental kemanusiaan yang masih ada karena selain memuat nilai-nilai humanis, juga membawa ruh keadilan. Keadilan 
merupakan satu hal yang fundamental ketika berbicara masalah transaksi perekonomian karena sesungguhnya ketidakadilan merupakan sumber permamsalahan yang kerap memunculkan ketimpangan,kemiskinan, dan kelaparan.

Dengan demikian, ekonomi Islam tidak hanya terhenti sebagai sebuah nama yang sarat akan nilai-nilai saja, tetapi juga diharapkan mampu melebur sebagai sebuah sistem yang handal dalam mengatur aktivitas perekonomian global yang didasari dengan kajian postivistik-empiris dan lebih bersifat objektif. Terbangunnya sebuah sistem sebagai pengejewantahan unifikasi antara duniawi dan ukhrowi akan mampu menjawab persoalan-persoalan mendasar kemanusiaan. Namun demikian, perlu dicatat bahwa tidak serta merta dengan adanya unifikasi tersebut lantas membawa perubahan, sehingga tidak memerlukan segala hal yang mendasarinya. Pengembang an berkelanjutan ilmu ekonomi tanpa dilapisi dengan muatan ajaran agama yang bersifat profetik, deduktif dan normatif, agaknya hanya akan segera terdominasi dan terkooptasi oleh kekuatan hukum ekonomi yang mempunyai logika kepentingannya sendiri. Begitu juga dengan minimnya kajian keilmiahannya secara objektif, akan mengakibatkan keberlanjutan ilmu ekonomi akan tergadaikan.

Berkaitan dengan itu, burhani sebagai salah satu dasar kajian ilmu pengetahuan dalam Islam seharusnya lebih digairahkan, paling tidak untuk mengimbangi bayani dan irfani yang selama ini cenderung lebih banyak digunakan sebagai dasar prospek pengembangan ilmu ekonomi Islam. Banyak fenomena praktek ekonomi Islam yang selama ini didasari dengan pendekatan intuitif. Praktek zakat misalnya hanya dipahami sebatas kewajiban agama, yang barang siapa yang menunaikannya, maka ia dapat pahala, dan barang siapa yang meninggalkannya maka ia akan mendapat dosa. Padahal sebenarnya, kewajiban zakat yang termaktub dalam al-Quran adalah tidak lain dan tidak bukan merupakan sebuah sistem agar bisa mengatasi kesenjangan sosial lantaran ketimpangan yang melanda sebagaian besar manusia. Dalam kajian antropologi ekonomi, para antroplog mengkatagorikan zakat sebagai salah satu fungsi ekonomi pada kajian redistribusi. Inilah salah satu titik yang menjadi perdebatan serius antara ekonomi formalis yang sarat dengan kultur matrealismenya (ekonomi pasar) dengan ekonomi substanstif (ekonomi tradsional) yang muncul sebagai perwujudan solidaritas sosial dan mengantongi nilai-nilai agama, ajaran dan budaya masyarakat yang mewadahinya.

Tentu hal di atas tidaklah salah, karena itu memang sudah konsekuensi logis sebagai akhir cerita, karena tanpa perspektif agama pun sudah dapat dipahami bahwa sistem ekonomi yang dibayangi dengan muatan individualistik, hedonistik pasti akan menimbulkan dosa, dan terjadinya krisis moneter berulang kali sehingga menciptakan kemiskinan, itulah bentuk kongkrit hukuman atas dosanya. Untuk menjawab itu semua, sesungguhnya epistimologi Islam yang meliputi bayani, irfani, dan burhani merupakan tiga serangkai yang tak bisa dipisahkan satu sama lain. Ketiganya berjalan di atas koredor yang seimbang dan proposional, sehingga dengan demikian, perjalanan perkembangan ekonomi Islam dengan sifatnya yang komplementer dan 
suplementer dapat menjadi kekuatan untuk membangun ekonomi yang handal dan mampu mengatasi permasalahan kemanusiaan fundamental.

\section{Epistimologi ilmu Ekonomi Islam}

Filsafat ekonomi Islam didasarkan pada tiga konsep yakni filsafat Tuhan, manusia dan alam. Kunci filsafat ekonomi Islam terletak pada manusia dengan Tuhan, alam dan manusia lainnya. Dimensi filsafat ekonomi Islam inilah yang membedakan ekonomi Islam dengan sistem ekonomi lainnya kapitalisme dan sosialisme. Filsafat ekonomi yang Islami, memiliki paradigma yang relevan dengan nilai-nilai logis, etis dan estetis yang Islami yang kemudian difungsionalkan ke tengah tingkah laku ekonomi manusia. Dari filsafat ekonomi ini diturunkan juga nilai-nilai instrumental sebagai perangkat peraturan permainan suatu kegiatan (Saifuddin, 1981:69).

Seperti disebut di atas bahwa salah satu poin yang menjadi dasar perbedaan antara sistem ekonomi Islam dengan sistem ekonomi lainnya adalah pada falsafahnya yang terdiri dari nilai-nilai dan tujuan. Dalam ekonomi Islam nilai-nilai ekonomi bersumber al-Qur'an dan Hadits berupa prinsip-prinsip universal. Di saat sistem ekonomi lain hanya terfokus pada hukum dan sebab akibat dari suatu kegiatan ekonomi, Islam lebih jauh membahas nilai-nilai dan etika yang terkandung dalam setiap kegiatan ekonomi tersebut. Nilai-nilai inilah yang selalu mendasari setiap kegiatan ekonomi Islam.

Bangunan Ekonomi Islam didasarkan pada fondasi utama yaitu tauhid, fondasi berikutnya adalah syariah dan akhlak. Pengamalan syariah dan akhlak merupakan refleksi dari tauhid. Landasan tauhid yang tidak kokoh akan mengakibatkan implementasi syariah dan akhlak terganggu. Dasar syariah adalah membimbing aktivitas ekonomi sehingga sesuaidengan kaidah-kaidah syariah. Sedangkan akhlak membimbing aktivitas ekonomi manusia agar senantiasa mengedepankan moralitas dan etika untuk mencapai tujuan. Akhlah yang terpancar dari iman akan membentuk integritas yang membentuk good corporate governance dan market diciplin yang baik. Dari fondasi ini muncul 10 prinsip derivatif sebagai pilar ekonomi Islam. Pembahasan komperhensif mengenai prinsip-prinsip ini selanjutnya akan dijelaskan secara lebih detail sebagai berikut (Anshari 1981:69):

\section{Tauhid}

Landasan filosofis inilah yang membedakan ekonomi Islam dengan ekonomi kapitalisme dan sosialisme, karena keduanya didasarkan pada filsafat sekularisme dan materialisme. Dalam konteks ekonomi tauhid berimplikasi adanya kemestian setiap kegiatan ekonomi untuk bertolak dan bersumber dari ajaran Allah, dilakukan dengan cara-cara yang ditentukan Allah dan akhirnya ditujukan untuk ketaqwaan kepada Allah. Konsep tauhid yang menjadi dasar filosofis ini, mengajarkan dua ajaran utama dalam ekonomi. Pertama, Semua sumber daya yang ada di alam ini merupakan ciptaan dan milik Allah secara 
mutlak dan hakiki. Manusia hanya sebagai pemegang amanah untuk mengelola sumberdaya untuk mewujudkan kemakmuran dan kesejahteraan kehidupan manusia secara adil. Kedua, Allah menyediakan sumber daya alam sangat banyak untuk memenuhi kebutuhan manusia. Manusia yang berperan sebagai khalifah dapat memanfaatkan sumber daya yang banyak itu untuk kebutuhan hidupnya. Dalam perspektif teologi Islam, semua sumber daya yang ada, merupakan nikmat Allah yang tak terhitung ( tak terbatas ) banyaknya(Anshari 1981:69).

Berbeda dengan pandangan di atas, para ahli ekonomi konvensional selalu mengemukakan pendapat bahwa sumber daya alam terbatas, karena itu menurut ekonomi Islam, krisis ekonomi yang dialami suatu negara bukan karena terbatasnya sumber daya alam melainkan karena tidak meratanya distribusi sehingga terwujud ketidak adilan sumber daya (Anshari 1981:70-71).

\section{Mashlahah}

Al-mashlahah sebagai salah satu model pendekatan dalam ijtihad menjadi sangat vital dalam pengembangan ekonomi Islam dan kebijakan ekonomi. Mashlahah adalah tujuan yangingin diwujudkan oleh syariat. Mashlahah merupakan esensi dari kebijakan-kebijakan syariah dalam merespon dinamika sosial, politik, dan ekonomi. Maslahah 'ammah (kemaslahatan umum) merupakan landasan muamalah, yaitu kemaslahatan yang dibingkai secara syar'i, bukan semata-mata profit motive dan material rentability sebagaimana dalam ekonomi konvensional.

\section{Adil}

Konsep sosio ekonomi dalam Islam berbeda secara mendasar dengan konsep keadilan dalam kapitalisme dan sosialisme. Keadilan sosio ekonomi dalam Islam selain didasarkan pada komitmen spritual juga didasarkan atas konsep persaudaraan universal sesama manusia. Al-quran secara eksplisit menekankan pentingnya keadilan dan persaudaraan tersebut.

\section{Khalifah}

Dalam doktrin Islam manusia diciptakan Allah untuk menjadi khalifah (wakil Allah) di muka bumi. Manusia telah diberkahi dengan semua kelengkapan akal, spiritual, dan material yang memungkinkannya untuk mengemban misinya dengan efektif. Fungsi kekhalifahan manusia adalah untuk mengelola alam dan memakmurkan bumi sesuai dengan ketentuan dan syariah Allah. Dalam mengemban tugasnya sebagai khalifah ia diberi kebebasan dan juga dapat berfikir serta menalar untuk memilih antara yang benar dan yang salah, baik dan buruk dan mengubah kondisi hidupnya ke arah yang lebih baik. Berbeda dengan paradigma kapitalisme, konsep khilafah mengangkat manusia ke status terhormat di dalam alam semesta. Serta memberikan arti dan misi bagi kehidupan baik laki-laki maupun wanita. Arti ini diberikan oleh keyakinan 
bahwa mereka tidak diciptakan dengan sia-sia tetapi untuk mengemban sebuah misi. Khalifah berbuat sesuai ajaran Tuhan dan berfungsi sebagai wakil wakil Tuhan di muka bumi.

Manusia bebas memilih berbagai alternatif penggunaan sumber-sumber ini. Namun karena ia bukan satu-satunya khalifah tetapi masih banyak milyaran lagi khlaifah dan saudara-saudranya, maka mereka harus memanfaatkan sumbersumber daya itu secara adil dan efisien sehingga terwujud kesejahteraan (falah) yang menjadi tujuan kegiatan ekonomi Islam. Tujuan ini hanya tercapai jika sumber-sumber daya itu digunakan dengan rasa tanggung jawab dan dalam batasbatas yang digariskan syariah dalam simpul maqashid. Konsep khilafah juga meniscayakan peranan negara dalam perekonomian. Peran penting tersebut antara lain memberikan jaminan sosial kepada masyarakat, jaminan pelaksanaan ekonomi Islam, serta kontrol pasar dan memastikan tidak terjadi pelanggaran terhadap hak-hak orang lain dalam kegiatan bisnis melalui lembaga hisbah. Peran negara dalam perekonomian tidak berarti bahwa Islam menolak mekanisme pasar sepenuhnya.

\section{Persaudaraan}

Al-Quran mengajarkan persaudaraan (ukhuwah) sesama manusia, termasuk dan terutama ukhuwah dalam perekonomian. Al-Quran mengatakan, "Hai manusia, sesungguhnya kami menciptakan kamu dari laki-laki dan perempuan dan menjadikan kamu berbangsa-bangsa dan bersuku-suku supaya kamu saling mengenal". (QS. al-Hujurat: 13). "Kami menjadikan kamu dari diri yang satu" (QS. Ali Imran: 1).

Ayat-ayat ini menjelaskan persamaan martabat sosial semua umat manusia di dunia. Kedudukan manusia adalah sama di hadapan Allah. Kriteria untuk menilai seseorang bukanlah bangsa, ras, warna kulit, tetapi tingkat pengabdian dan ketaqwaanya kepada Allah secara vertikal dan kemanusiaan secara horizontal. Nabi Muhamd Saw mengatakan "Sebaik-baik manusia adalah orang yang bermanfaat bagi orang lain".Ajaran Islam sangat kuat menekankan altruisme, yaitu sikap mementingkan orang lain. Dalam Al-Quran altruisme diistilahkan dengan itstar yang termaktub dalam firman Allah, Mereka lebih mementingkan orang lain dari diri mereka sendiri, sekalipun mereka dalam keadaan kesulitan". Ajaran ini jelas tidak terdapat dalam ekonomi kapitalisme. Sebagaimana disebut diatas bahwa Islam mengajarkan konsep al-musawat (persamaan) diantara sesama manusia. Semua sumber daya alam, flora dan fauna ditundukan oleh Allah bagi manusia manapun sebagai sumber manfaat ekonomis . Di sini tampak jelas konsep persamaan manusia dalam pengelolaan dan pemanfaatan sumber daya.

Konsep persamaan manusia, menunjukan bahwa Islam menolak pengklasifikasian manusia yang berdasarkan atas kelas-kelas. Implikasi dari doktrin ini ialah bahwa antara manusia terjalin rasa persaudaraan dalam kegiatan ekonomi, saling membantu dan bekerjasama dalam ekonomi yakni syirkah, qiradh dan mudharabah. Inilah yang diterapkan di dalam aktivitas 
ekonomi mikro di lembaga-lembaga keuangan Islam saat ini seperti bank syari'ah, asuransi syari'ah, obligasi syari'ah, pasar modal syariah, Baitul Mal wat Tamwil (BMT). Dalam konteks ekonomi makro praktik bagi hasil ini diterapkan dalam pinjaman luar negeri, dalam instrumen moneter pemerintah sehingga sistem riba benar-benar dihapuskan dalam seluruh aktivitas ekonomi baik mikro maupun makro.

\section{Kerja dan Produktifitas}

Dalam Islam bekerja dinilai sebagai suatu kebaikan, dan sebaliknya kemalasan dinilai sebagai keburukan. Dalam kepustakaan Islam cukup banyak buku-buku yang menjelaskan secara rinci tentang etos kerja dalam Islam. Dalam pandangan Islam bekerja dipandang sebagai ibadah. Sebuah hadits menyebutkan bahwa bekerja adalah jihad fi sabilillah. Sabda Nabi Saw, "Siapa yang bekerja keras untuk mencari nafkah keluarganya, maka ia adalah mujahid fi Sabillah". Dalam hadits Riwayat Thabrani Rasulullah Saw bersabda : "Sesungguhnya, di antara perbuatan dosa, ada yang tidak bisa terhapus oleh (pahala) shalat, Sedeqah ataupun haji, namun hanya dapat ditebus dengan kesungguhan dalam mencari Nafkah penghidupan" (H.R. Thabrani). Dalam hadits ini Nabi Saw ingin menunjukkan betapa tingginya kedudukan bekerja dalam Islam, sehingga hanya dengan bekerja keras (sunguh-sungguh) suatu dosa bisa dihapuskan oleh Allah.

Dalam sebuah hadits Rasul saw bersabda "Barang siapa pada malam hari merasakan kelelahan karena bekerja pada siang hari, maka pada malam itu ia diampuni Allah". Sedangkan Hadits Riwayat Ahmad \& Ibnu Asakir "Apabila kamu telah selesai shalat subuh, maka janganlah kamu tidur". Hadits ini memerintahkan agar manusia menyegerakan bekerja sejak pagi-pagi sekali, agar ia menjadi produktif. Bahkan Nabi SAW secara khusus mendoakan orang yang bekerja sejak pagi sekali "Ya Allah, berkatilah ummatku yang bekerja pada pagipagi sekali”.

\section{Kepemilikan}

Dalam kapitalisme yang menganut asas laisssez faire, hak pemilikan perorangan adalah absolut tanpa batas. Terjaminnya kebebasan memasuki segala macam kegiatan ekonomi dan transaksi menurut persaingan bebas. Sedangkan dalam marxisme, hak memiliki hanya untuk kaum proleter yang diwakili oleh kepemimpinan diktator. Distribusi faktor-faktor produksi dan apa yang harus diproduksi ditetapkan oleh negara. Pendapatan kolektif dan distribusi yang kolektif adalah ajaran utama, sedangkan hubungan-hubungan ekonomi dalam transaksi secara perorangan sangat dibatasi. Berbeda dengan kapitalisme dan sosialisme, dalam ekonomi Islam, pemilikan hakiki hanya pada Allah. Allah adalah pemilik mutlak (absolut) sedangkan manusia memegang hak milik relatif, artinya manusia hanyalah sebagai penerima titipan, pemegangamanatharus mempertanggung jawabkannya kepada Allah. Jadi, menurut ekonomi Islam, penguasaan manusia 
terhadap sumberdaya, faktor produksi atau aset produktif hanyalah bersifat titipan dari Allah. Pemilikan manusia atas harta secara absolut bertentangan dengan tauhid, karena pemilikan sebenar hanya ada pada Allah semata.

\section{Kebebasan dan Tanggung Jawab}

Prinsip kebebasan dan tanggung jawab dalam ekonomi Islam pertama kali dirumuskan oleh An-Naqvi. Kedua prinsip tersebut, masing-masing dapat berdiri sendiri, tetapi doleh beliau kedua prinsip tersebut digabungkan menjadi satu. Penyatuan ini dilakukan karena kedua prinsip itu memiliki keterkaitan yang sangat kuat. Penyatuan ini juga dimaksudkan agar pembaca dengan cepat menangkap pengertian kebebasan dalam kajian ini, sehingga tidak muncul tanda tanya dan kerancuan dalam pikiran tentang makna kebebasan dalam persepektif Islam. Pengertian kebebasan dalam perekonomian Islam difahami dari dua perspektif, pertama perspektif teologi dan kedua perspektif ushul figh/falsafah tasyri'.

Pengertian kebebasan dalam perspektif pertama berarti bahwa manusia bebas menentukan pilihan antara yang baik dan yang buruk dalam mengelola sumberdaya alam. Kebebasan untuk menentukan pilihan itu melekat pada diri manusia, karena manusia telah dianugerahi akal untuk memikirkan mana yang baik dan yang buruk, mana yang maslahah dan mafsadah (mana yang manfaat dan mudharat). Adanya kekebasan termasuk mengamalkan ekonomi, implikasinya manusiaharus bertanggung jawab atas segala perilakunya. Manusia dengan potensi akalnya mengetahi bahwa penebangan hutan secara liar akan menimbulkan dampak banjir dan longsor. Manusia juga tahu bahwa membuang limbah ke sungai yang airnya dibutuhkan masyarakat untuk mencuci dan mandi adalah suatu perbuatan salah yang mengandung mafsadah dan mudharat.

Seandainya manusia berkeyakinan bahwa ia melakukan perbuatan itu karena dikehendaki Allah secara jabari, maka tidak logis ia diminta pertanggung jawaban atas penyimpangan perilakunya. Jadi makna kebebasan dalam konteks ini bukanlah manusia bebas tanpa batas melakukan apa saja sebagaimana dalam faham liberalisme. Jadi, kebebasan dalam Islam bukan kebebasan mutlak, karena kekebasan seperti itu hanya akan mengarah kepada paradigma kapitalis laisssez faire dan kebebasan nilai (value free).

Kebebasan dalam pengertian Islam adalah kekebasan yang terkendali (alhurriyah al-muqayyadah).Dengandemikian,konsep ekonomi pasar bebas tidak sepenuhnya begitu saja diterima dalam ekonomi Islam. Alokasi dan distribusi sumber daya yang adil dan efisien, tidak secara otomatis terwujud dengan sendirinya berdasarkan kekuatan pasar. Harus ada lembaga pengawas dari otoritas pemerintah yang dalam Islam disebut lembaga hisbah. Kebebasan dalam konteks kajian prinsip ekonomi Islam dimaksudkan sebagai anti tesis faham jabariyah (determenisme). Faham ini mengajarkan bahwa manusiabertindak dan berperilaku bukan atas dasar kebebasannya pilihannya sendiri, tetapi atas kehendak Tuhan. 
Pengertian kebebasan dalam perspektif ushul figh berati bahwa dalam muamalah Islam membuka pintu seluas luasnya di mana manusia bebas melakukan apa saja sepajang tidak ada nashyang melarangnya. Aksioma ini didasarkan pada kaedah, pada dasarnya dalam muamalah segala sesuatu dibolehkan sepanjang tidak ada dalil yang melarangnya. Bila diterjemahkan arti kebebasan bertanggng jawab ini ke dalam dunia binsis, khususnya perusahaan, maka kita akan mendapatkan bahwa Islam benar-benar memacu ummatnya untuk melakaukan inovasi apa saja termasuk pengembangan teknologi dan diversifikasi produk.

\section{Jaminan Sosial}

Penjelasan sebelumnya telah menjelaskan bahwa Islam menuntut kepada setiap orang yang mampu untuk bekerja dan bersungguh-sungguh dalam kerjanya, sehingga ia dapat mencukupi dirinya dan keluarganya. Namun demikian, beberapa anggota masyarakat ada yang tidak mampu bekerja, sehingga mereka tidak berpenghasilan. Ada juga yang mampu bekerja, tetapi tidak mendapatkan lapangan kerja sebagai sumber penghasilan mereka dan pemerintah sendiri tidak mampu untuk mempersiapkan lapangan kerja yang sesuai bagi mereka. Ada pula yang sebenarnya sudah bekerja, hanya saja pemasukan mereka belum mencukupi standar yang layak, karena sedikitnya pemasukan (income) atau banyaknya keluarga yang ditanggung atau mahalnya harga barang atau karena sebab-sebab yang lain. Untuk mengatasi problem tersebut Islam mengajarkan takaful al-ijtima'iy (jaminan sosial), melalui isntrumen zakat, infak, sedeqah dan wakaf.

\section{Nubuwwah}

Prinsip ekonomi Islam yang terakhir adalah nubuwwah yang berarti kenabian. Prinsip nubuwwah dalam ekonomi Islam merupakan landasan etis dalam ekonomi mikro. Prinsip nubuwwah mengajarkan bahwa fungsi kehadiran seorang Rasul atau Nabi adalah untuk menjelaskan syariah Allah SWT kepada umat manusia. Prinsip nubuwwah juga mengajarkan bahwa Rasul merupakan personifikasi kehidupan yang baik dan benar. Untuk itu Allah mengutus Nabi Muhammad Saw sebagai Rasul terakhir yang bertugas untuk memberikan bimbingan dan sekaligus sebagai teladan kehidupan. Sifat - sifat utama yang harus diteladani oleh semua manusia (pelaku bisnis, pemerintah dan segenap manusia) dari Nabi Muhammad, setidaknya ada empat, yaitu shiddiq, amanah, tabligh dan fatanah.

\section{Penutup}

Dalam rangka mengembangkan Ekonomi Islam, tidak bisa tidak, pengelaborasian secara objektif ilmiah menjadi suatu yang mutlak. Ekonomi Islam sebagai sebuah disiplin ilmiah ( scientific discipline) selayaknya, selain dikaji secara deduktif- normatif yang sarat dengan nilai-nilai, tetapi juga harus dibangun atas dasar kajian induktif yang berbasis rasionalistik-empirik. 
Keseimbangan kajian secara induktif-deduktif merupakan harga mati yang tidak bisa ditawar-tawar lagi. Pengembangan yang berkelanjutan dari ilmu ekonomi di satu sisi, tanpa dilapisi dengan muatan ajaran agama yang bersifat profetik dan normatif, agaknya hanya akan segera terdominasi dan terkooptasi oleh kekuatan hukum ekonomi yang mempunyai logika kepentingannya sendiri. Di sisi lain, tanpa kajian objektif ilmiah, pengembangan ilmu ekonomi Islam agaknya akan terseok-seok dalam menjawab permalahan aktivitas perekonomian yang semakin kompleks. Filsafat ilmu sebagai sebuah proses pengelaborasian tentang karakteristik disiplin ilmiah (scientific discipline) dan bagaimana cara memperolehnya (epistimic), menjadi hal yang sangat mungkin sekali untuk dijadikan referensi dasar sebagai pengembangan ekonomi Islam 


\section{DAFTAR PUSTAKA}

Anshari, Endang Saiffudin. 1981. Ilmu Filsafat Dan Agama. Surabaya: PT.Bina Ilmu.

Hassan, Fuad. 1989. Berkenalan Dengan Filsafat Eksistensialisme. Jakarta: Pustaka Jaya.

Huda, Nurul. 2007. Ekonomi Makro Islam Pendekatan Teoritis. Jakarta: Kencana.

Iswadi, Muhammad. 2007. "Ekonomi Islam: Kajian Konsep Dan Model Pendekatan." Jurnal Mazahib 4(1).

Minhaji, Akhmad. 2008. Ekonomi Dan Lembaga Keuangan Islam. Kediri: Qubah.

Nasution, Harun. 1991. Filsafat Agama. Jakarta: Bulan Bintang.

Qardhawi, M. Yusuf. 1987. Norma Dan Etika Ekonomi Islam. Jakarta: Gema Insani Press.

Suyatno, Thomas. 1997. Kelembagaan Perbankan. Jakarta: STIE PERBANNAS dan Gramedia Pustaka Utama.

Tafsir, Ahmad. 1990. Filsafat Umum. Bandung: PT. Remaja Rosdakarya.

Wiramihardja, Sutardjo A. 2006. Pengantar Filsafat. Bandung: PT. Refika Aditama. 